\title{
Oh, Mother, Who Art Thou? : The Heart of Maternal Darkness in the Short Stories of Katherine Mansfield
}

\author{
Anindita Sarkar \\ MPhil Research Scholar \\ Jadavpur University \\ Kolkata, West Bengal, India \\ aninditasar2@gmail.com
}

\begin{abstract}
Our culture assumes: No love is as great as that of a mother for her child. Motherhood has been perpetually associated with self-effacement and self-abnegation. Adrienne Rich while making a distinction between the actual lived experience of a mother and the institution of motherhood has argued that motherhood is a cultural construct and a far cry from the real experience of mothering. This article traces and examines representations of motherhood in the select short stories of Katherine Mansfield, in the light of Adrienne Rich's theories in $O f$ Woman Born. Much like Adrienne Rich, Mansfield discredits the traditional assumption that to be a mother is an essential pre-requisite to be a 'real woman'. Mansfield's women characters unleash a plurality of voices that aid the readers at viewing maternity as an ambiguous experience. Instead of romanticizing and idealizing the mother-daughter relationship, she offers a problematic connection between both the figures, often pitting them as rivals against each other. Her women characters progressively revolt from within the four walls of the hou sehold by their intermittent display of anger and deliberate attempts at failing to conform to the monolithic ideals of femininity.
\end{abstract}


Keywords: Cultural construct, real experience, ambiguous, failure to conform

Motherhood has been considered as essentialism and an indispensable part of the female experience since antiquity. The patriarchal construct of motherhood and its infallibility can be traced back to the classic division of labour and men's obsession with commodity fetishism. Women due to their procreating ability were entrusted with the task of looking after the home and hearth, while men toiled in the public sphere. Mothers since inception have been reified as a Madonna-like figure who must efface herself for the welfare of her children. Several feminist scholars have neglected the study of motherhood as a distinct discipline and labeled it as a hindrance to actual feminist concerns of identity and liberation.

Motherhood has been venerated and offered a positive status as an experience rather than a biological institution, since the publication of Adrienne Rich's manifesto 'Of Woman Born: Motherhood as Experience and Institution'. Through her work Rich argues that Patriarchy has dubiously tended to idealize women as mothers, transforming motherhood into an infallible social function, only to oppress women within the constraints of the heteronormative family. Rich calls for the need to demystify this dogma associated with motherhood in order to incorporate the untainted detailed experience of women actually dealing with it. "To destroy the institution (of motherhood) is not to abolish motherhood", Rich reminds us, thus she refutes the anti-motherhood claims of her predecessors Simone de Beauvoir and Betty Friedman who proclaimed that a woman's fertility was the source of her subordination. (Rich, 280) Throughout her life, Katherine Mansfield has oscillated between her personal space and her career as an artist while also battling with a lethal pulmonary disease. The mother characters in her short stories much like herself, struggle to find a stable identity of their own, in a disillusioned world, battling the unsettling forces of patriarchy. 
The 'childish subject' in Mansfield is a common theme, this childlike yearning expressed by the female characters in her short stories doesn't merely mean a wish to return to the phase of youthful bliss but it also implies the resistance to adult modes of behaviour. The overtures of childishness and childlike behavior are significant touchstones through which the women characters dwell on a life of fantasy and illusion. The protagonist Sabina in Mansfield's short story At Lehmann'sis a freshly recruited worker at the coffee shop of Lehman, who oscillates between the sweetness of sex and the nightmarish thoughts of childbirth trauma. Throughout the short story, Sabina consciously monitors the expectant wife of the owner of the coffee shop Frau Lehmann. The topic of bodily distortion entailed by childbirth is startlingly candid in this short story. Although Sabina was practically unknown to the labyrinthine ways associated with pregnancy and childbirth, she was aware that "it was very painful indeed."'(Mansfield, 9) The other workers at the café mockingly addressed Frau's embracement of motherhood as "bad time approaching", thus by equating childbirth and nurturance to bad time signifies the toil and trouble it would take to bring up the child.( 9) It also suggests the end to a woman's freedom and infantile impulses for the sake of the 'other'. The uncouth, unappealing remark that Sabina makes on witnessing the obese Frau, who whiled away her time knitting clothes for her child: "I wouldn't be the Frau for one hundred marks", speaks volumes of her resentment towards motherhood. (11)

The notion that childbirth causes wreckage of the female body is advocated through, Lehmann's own remark on his expectant wife. He labelled her as "unappetizing" and recommended her to stay upstairs in her room, aloof from others as her "monstrously pregnant body" could scare away his customers.(9)Frau's perverse dependency and powerlessness like an invalid woman made her viciously frustrated. Her frustration with her own burgeoning body is evident through her angry replies to anybody who would ask her anything. Frau's dependency smothers every other character in the short story. 
The deep-seated patriarchal ideology of Herr Lehmann is clearly visible when he rejects to be near his wife Frau, while he selfishly reveled in spending time with his friends. As a part of the general rule of the universe, he assumed that bringing up a child and nurturing it was solely the responsibility of the women. This carelessness on his part and the void created due to it, angered Frau even more, who fervently wished to bring up the child with her cohort. Frau self-pityingly lashed out at Sabina when she informed her that her husband was busy playing cards over at Snipold's, "Dear heaven, leave him alone. I'm nothing. I don't matter." (10)

On witnessing Frau's self-annihilation into the vortex of motherhood, Sabina develops a furious hatred against childbearing. Her short-lived reveries of a romantic liaison with the Young Man with snow-powdered hair who frequented the café comes to abeyance when Sabina realizes that exploring her sexuality could land her into a pregnancy. The vivid flash of a cry by the newborn baby, near the end of the short story,that interrupts the romantic moment between Sabina and the Young Man suggests an awakening for Sabina. Sabina subsequently departs from the scene realizing that she shouldn't put her body at stake to be violently ruptured by the 'other' (child). Thus it can be conjectured that Mansfield has used this short story as a cautionary tale against the institution of motherhood, an ultimate deterrent to a woman's personality.

The story Frau BrechenmacherAttends a Wedding, is a tale of an overworked mother of five children, who wishes to evade her responsibilities, but is rendered helpless due to the incessant demands of her children and husband. The character of Frau allegorizes that of a debilitate woman who has to toil persistently for her family without any acknowledgement from them. According to Rich the "mother at home" woman often suffers from an ill temper due to her muffled state within the four walls of the household, and finding no transit, she channelizes her rage on her children. (Rich, 111) Frau manifests her anger wrought out by the 
end of her adolescent fervor and fueled by her maternal consciousness, by moral policing her eldest daughter Rosa. "Rosa, fetch my dress", "Rosa, give your father the towel", Frau commanded.(Mansfield,12) Frantz Fanon has argued in his book Black Skin White Masks that the colonized have a tendency to impersonate their masters and create power dynamics within their own community, in order to vent out their anger and appease their inflicted ego. Frau Brechenmacher too was a colonized subject in the hands of patriarchy, by cajoling Rosa into submission, Frau acquired an empowering opportunity within the constraints of her household.

According to Helene Deutsch's assumption in her book The Psychology of Women: A Psychoanalytic Interpretation, the mother's most significant anxiety is the fear of losing her personality in favour of the child. Frau's self identity was already extinct after bearing five children with her husband. The persecution that Frau had undergone due to childbirth terrorized her now and then. Frau's debilitate state is clearly visible during the wedding that she and her husband attends. Frau was disgusted at the spectacle of the guests swaying in laughter while witnessing her husband bestow the newly wedded bride with a baby's bottle and two little cradles holding China dolls. Her indignation exemplifies her denial of the patriarchal rationalizations associated with marriage and the destiny of a woman thereafter. Her wish to "go home and never come out again" reflects her embarrassment. A dizziness suddenly possessed her body as she interpreted the guests laughing at her own thwarted condition, with five babies already in her coffer.

Through the subtle mention of death in the light of the beginning of a new life, Mansfield ridicules the adage that a woman's marriage offers her with a new identity of a wife and then a mother. At the wedding when the bride's mother gazes at her daughter with solemnity, her husband throws a jibe at her saying "cheer up!" ; "this isn't Theresa's funeral." (Mansfield, 14) Thus by alluding a woman's marriage to her death Mansfield suggests, not 
only the death of a woman's authentic identity, dreams and aspirations but also her impending domestication. The ending of the short story yet again displays the mindlessness of the male counterpart when, after returning back to their home, Frau's husband forces himself upon her without her consent. Frau's disdain at the drudgery of her life with year in, year out pregnancies is evident from her regretful expletive: "always the same", as she lay down on the bed waiting to be hurt as Herr Brechenmacher lurched in.( 16)

The Death-mother archetype and its psychodynamic perspective had no place in the cultural consciousness during the time Mansfield was writing. The Death-mother archetype symbolizes a woman who is unable to love her children instinctively and selflessly. Despite of the fact that this archetype wasn't acknowledged during Mansfield's time, it has always been a part of our collective cultural and embodied heritage. Through her short story The Woman at the Store Mansfield has tried to humanize the death-mother archetype in order to dismantle the self-perpetuating cycles of shame that constellate around this archetypal energy. The unnamed woman at the store is an abandoned wife and a mother of a six year old child, who had relinquished her career as a bar dancer to dedicate herself to her family. She is notoriously rumored to have known hundred and five ways of kissing, as is evident by the slandering remarks of the travelers who decide to stay overnight at her paddock.

According to feminist critics, childbirth can put a woman into a corporeal discipline which further leads to detached parenting on part of the woman. In the short story the unnamed woman had silenced her carnal fantasies after being assigned the salutary and sobering role of motherhood. However the perpetual trivialization of her daughter and her estrangement towards her reveals that she was 'forcibly' made to relinquish her promiscuous nature. The woman's vexed reply to the traveler on being inquired about the child's paternity: "No, she's the dead spit of me", signifies her unrelenting maternal toil that had outstripped 
her of her beauty. By equating her daughter with her 'spit' she pours out her repugnance towards her mini self whom she regarded as an unwanted product.

Rich has contended in her book Of Woman Born that a woman must be the presiding genius of her own body, thus suggesting that a woman must be able to take choices unquestionably about her own female flesh. Mansfield through her finesse shows that a rebellious woman's true nature cannot be stifled even after being bludgeoned by the responsibility of maternity. The unnamed woman invited the travelers to stay at her paddock for the night with an ulterior motive. She had actually planned to share her bed with Jo, the overtly flirtatious man from the group of the three travelers, thus trying to reclaim her sexuality. Her distaste for the hierarchical imbalance of power is evident whenever she is questioned about her husband. She felt humiliated on being questioned about living alone with a child in a sequestered paddock, without the help of a male figure to protect them. "Now listen to me", she shouted to the travelers to put an end to their inquiries and justified about the reason of her hatred towards her husband, "you've (he has) broken my spirit and spoiled my look." (Mansfield, 27) Through her confession, she crystallizes how patriarchy is bent on denying a woman with a standpoint of her own.

Breaking away from the canonized description of an ideal wife, she candidly voices out her hatred for her heedless husband. The woman at the store lived her life on her own terms in the absence of her husband but the child was the primary source of her wretchedness. She dressed up gaudily for Jo at the dinner table to seduce him for the night, and she also made ridiculous sleeping arrangements: Jo was offered the bedroom, Jim and the narrator was to share the storeroom with her six-year daughter. By allowing her daughter to share the room with the strangers, the woman embraces her long lost unencumbered life for the night and neglects her role as a mother. 
Adrienne Rich explains the concept of the term 'Matrophobia' borrowed by Lynn Sukenick, which means "the fear not of one's mother but of becoming one's mother." (Rich, 127) Matrophobia essentially means "the desire to become purged once and for all our mother's bondage." (117) Rich explains that the hatred that a daughter fosters for her mother is an attempt to evade a similar fate suffered by her mother, which has rendered her into a cipher. The Woman at the store shares an acerbic relationship with her daughter. The daughter tempestuously disobeys her mother and spends much of her time drawing. The friction-laden relationship between them is clearly visible when the daughter obdurately goes against her mother's warnings, by sketching the incident which her mother had especially asked her not to: "the picture of a woman shooting a man with a rook rifle and then digging a hole to bury him."( Mansfield28) Thus to blur and overlap the void created by their malevolent relationship she resorted herself into art. The revelation through the daughter's drawing also throws an important light on the malicious aspect of incarceration. Although the woman never accepts that her husband had died or that she had silenced him forever, the picture reeks of her criminality. It must be concluded that she had killed him out of frustration for endowing her with a child and therefore a life bereft of pleasure, robbing her of her subjectivity.

Mansfield is commendable for evocating subjective maternal experiences through her writing that counters socio-cultural expectations, patriarchal repression and literary misrepresentations. By displaying the complexity that belies in the heart of a mother, Mansfield offers a new and empowering maternal aesthetics and poetics that is dialogical and hospitable, open to both realities and wary of dichotomies. The opening lines of the short story The Garden Party acquaint us with Mrs Sheridan the maternal subject with five children, who wishes to be carefree from the drudgery of her daily existence. Although she is a member of the genteel bourgeoisie, she is not unblemished by the responsibilities of 
motherhood. The penchant of unbecoming a mother is clearly visible from the petulant statement to her daughter, on being asked about the preparations for the garden party that they were hosting: "forget I am your mother. Treat me as an honoured guest."( Mansfield, 212) According to Margaret Mahler's theory on the development of a child, there lies a parasite- host relationship between a child and its mother. The child perceives the mother as an idealized object during infancy and cannot distinguish between the mother from itself. But as the child develops it suffers from a dual fear: the anxiety of being separated from the mother as well as anxiety of framing an identity of its own. This dual fear is starkly visible through the dilemmas and actions of Mrs Sheridan's daughters who try to make the garden party a success through their individual efforts but end up seeking help from their mother.

In the character of Mrs Sheridan we find a double entendre. On one hand, she wishes to be unencumbered by the maternal duties entrusted to her. On another hand, she persistently kept a watchful eye on her children. When the telephone rang and Laura ran to answer it, Mrs Sheridan who was absent from the scene, shouted exuberantly from upstairs to make herself heard and reminded Laura to tell the caller "to wear that sweet hat she had on last Sunday."( Mansfield, 214) Thus by making her essence felt even in her absence, she tried to usurp her children's autonomy. It is important to note that Mrs Sheridan herself is a colonized subject at the hands of her husband, therefore by terrorizing her daughters through her omnipresence she attains a sense of agency within the domestic space. Her vigilant attitude is not to be interpreted as a result of her concern for her children, Mrs Sheridan is not a hostage of maternal consciousness rather she assumes the role of a colonizer incarcerating her children's free movement and curbing their decision making powers.

The amorphous nature of Mrs Sheridan intensifies when we come to know about her fascination with 'canna lilies' : "big pink flowers, wide open, radiant, almost frighteningly alive on bright crimson stems."( Mansfield, 215) The canna lilies personify the psychology of 
Mrs Sheridan, suggesting that she is a woman who herself is living a life of servitude and it is only by trespassing into the lives of her daughters that she is able to revitalize her diminished sense of self. Her antagonism towards patriarchy and especially her husband is evident when Laura opined about cancelling the garden party due to the death of their financially insolvent neighbour. Laura was visibly shaken by the sudden death of a man in their neighbourhood who was outlived by his wife and five little children. Laura's sympathetic consciousness drew an uncanny resemblance between her family and the family of the deceased. Laura was pained by her mother's stoic attitude. But Mrs Sheridan's refusal to her opinion: "You are being absurd, Laura", was harder to bear than her sister Jose's because her mother seemed amused.(216)Mrs Sheridan's 'amusement' reveals her unscrupulous sadism. Mrs Sheridan in her imagination might have posited herself in place of the wife of the dead, and it perhaps gave her a momentary satisfaction from the stultifying presence of patriarchy. The tinge of amusement in her response to Laura is an outcry motivated by her maimed sense of self and disempowerment under the masculine principles of patriarchy.

Predominantly in all cultures, the women, especially the mothers have to face the brunt of patriarchy. It is the mother who has been always criminalized and trivialized to appease the fragile male ego. She is an object of mistrust, guilt and suspicion. Rich avers through her book to lend voices to the silenced mothers in order to confer them with subjectivity and allow them a space that the canonical literature often neglects. Mansfield through her short stories has righteously acquainted us with a plethora of experiences associated with maternity helping us to know motherhood in full meaning and capacity. 


\section{References}

Ainsworth, Mary D. Salter. “Object Relations, Dependency and attachment: A theoretical Review of the Infant-Mother Relationship." Child Development Review, 1969, pp. $969-1025$.

Burgan, Mary. "Childbirth Trauma in Kathrine Mansfield's Early Stories." Modern Fiction Studies, 24, 1978, pp. 395-412.

Fanon, Frantz. Black Skin, White Masks. Pluto Press, 1967, pp. 109-127.

Hankin, C.A. Kathrine Mansfield and her Confessional Stories. The MacMillan Press, 1983. Print.

Mahler, M.S. "Mother-Child Interactionduring separation-individuation." Psychoanalytic Quarterly, 34, 1985, pp. 83-198

Mansfield, Katherine. The Short Stories of Katherine Mansfield. Digireads Publication, 2009. Print.

Moran, Patricia. "Unholy Meanings :Maternity, Creativity, and Orality in Kathrine Mansfield.” Feminist Studies, 17, 1991, pp. 105-125

Rich, Adrienne. Of Woman Born. New York: London, 1986. Print. 